\title{
Hepatic Injury Induced by a Single Dose of Nivolumab - a Case Report and Literature Review
}

\author{
Postižení jater po jedné dávce nivolumabu - kazuistika \\ a přehled literatury
}

\author{
Kopecky J. ${ }^{1}$, Kubecek O. ${ }^{1}$, Geryk T. ${ }^{2}$, Podhola M. ${ }^{2}$, Ziaran M. ${ }^{1}$, Priester P. ${ }^{1}$, Hanisova M. ${ }^{1}$, Borilova S. ${ }^{1}$ \\ 1 Department of Oncology and Radiotherapy, Faculty of Medicine, University Hospital Hradec Kralove \\ ${ }^{2}$ The Fingerland Department of Pathology, Faculty of Medicine, University Hospital Hradec Kralove
}

\begin{abstract}
Summary
Background: The use of nivolumab in the treatment of metastatic melanoma has become well established during past years. Despite its undeniable efficacy, immune-related side effects may occur, including acute liver injury. Liver toxicity caused by nivolumab is usually observed as liver enzyme elevation with mild or no symptoms; further, there is limited information regarding any histopathological findings. Case: We report a case of a 38-year-old woman with metastatic melanoma who developed unusual nivolumab-induced hepatic injury after a single dose of nivolumab. A liver biopsy was performed to assess the aetiology of hepatic lesions as no other analysis concerning biochemistry, virology, autoantibodies, nor imaging studies revealed any pathology. The histopathological analysis showed an oedema in the portal fields and mixed inflammation consisting of eosinophilic and neutrophilic granulocytes. The major finding was a prominent, predominantly intracellular, cholestasis. Conclusion: To our knowledge, no such histopathological pattern of liver injury has been described in relation to nivolumab therapy elsewhere. This type of liver injury shows higher resistance to corticosteroids, which may warrant upfront high-dose corticotherapy combined with other immunosuppressive agents, including mycophenolate mofetil. This case highlights a necessary awareness regarding immunotherapy-related adverse events, which could be severe and potentially life-threatening.
\end{abstract}

Key words

nivolumab - hepatitis - toxicity - corticosteroids - autoimmunity

\section{Souhrn}

Východiska: Použití nivolumabu v léčbě metastatického melanomu se $v$ uplynulých letech stalo terapeutickým standardem. I přes jeho nepopiratelnou účinnost se však mohou objevit nežádoucí reakce, vč. akutního poškození jater. Hepatotoxicita způsobená nivolumabem je obvykle popisována jako zvýšení hladin jaterních enzymů s přiznaky či bez př́znaků. Informace o histopatologických projevech této toxicity existují v omezené míre. Případ: Uvádíme př́pad 38leté ženy s metastazujícím maligním melanomem, u které došlo k poškození jater po jedné dávce nivolumabu. Jelikož žádné vyšetření v podobě biochemie, virologie, autoprotilátek ani zobrazovacích metod neodhalilo př́činu jaterního selhávání, byla provedena jaterní biopsie. Histopatologické vyšetření prokázalo edém v portálních polích a smíšený zánět sestávající z eozinofilních a neutrofilních granulocytů. Hlavním nálezem byla prominentní, převážně intracelulární cholestáza. Závěr: Podle našich znalostí nebyl tento typ jaterního postižení v souvislosti s léčbou nivolumabem dosud popsán. Tento typ jaterního poškození může být spojován s vyšší rezistencí na léčbu kortikosteroidy, s nutností agresivnějšího prístupu či s použitím dalších imunosupresiv, jako např. mykofenolátu mofetil. Tento př́pad dále upozorňuje na potřebnou obezřetnost, ale i nutnost dobré informovanosti o možných nežádoucích účincích souvisejících s imunoterapií, které, ač nemusejí být časté, mohou být potenciálně život ohrožující.
The study was supported by the Charles University Faculty of Medicine in Hradec Kralove grant SVV- 2016-260286 and UK Progres Q40/06.

Tato studie byla podpořena grantem SVV- 2016260286 a UK Progres (Q40/06) Lékařské fakulty Univerzity Karlovy v Hradci Králové.

The authors declare they have no potential conflicts of interest concerning drugs, products, or services used in the study.

Autor̆i deklarují, že $v$ souvislosti s předmětem studie nemaji žádné komerční zájmy.

The Editorial Board declares that the manuscript met the ICMJE recommendation for biomedical papers.

Redakční rada potvrzuje, že rukopis práce splnil ICMJE kritéria pro publikace zasílané do biomedicínských časopisů

MUDr. Jindřich Kopecký, Ph.D.

Department of Oncology and

Radiotherapy

University Hospital

Hradec Kralove

Sokolska 581

50005 Hradec Kralove

e-mail: kopecjin@fnhk.cz

Submitted/Obdrženo: 31. 12. 2018

Accepted/Přijato: 20. 2. 2019

doi: 10.14735/amko2019133

Klíčová slova

nivolumab - hepatitida - toxicita - kortikosteroidy - autoimunita 


\section{Introduction}

The use of nivolumab in the treatment of metastatic melanoma has become well established during past years [1]. Nivolumab, a human monoclonal antibody targeting the programmed cell death receptor 1 (PD-1), has proven to be of great benefit in overall survival in patients with metastatic malignant melanoma; however, despite its undeniable efficacy, major side effects may occur. These are usually immune-related and may be present in various forms, including acute liver injury, a potentially serious and life-threatening event. Although the liver toxicity of nivolumab has been reported in clinical trials, it is usually described as increased liver enzyme, with none or limited information regarding histopathological observations. The risk of severe immune-related hepatic injury is generally considered to be lower and less common with anti-PD-1 therapy when compared to anti-CTLA-4 antibodies [2,3].

Herein, we report a case of unusual onset of nivolumab-induced hepatic in- jury after a single dose of nivolumab. Furthermore, we provide a thorough histopathological study of the liver tissue specimen and discuss possible pathogenesis and treatment options.

\section{Case report}

The present study concerns the case of a 38-year-old woman with metastatic melanoma (Schema 1) who developed severe hepatic injury after the first dose of nivolumab. Fourteen days following the introduction of nivolumab therapy, the patient visited the outpatient clinic to obtain a second dose; she had no symptoms of immune-related adverse events (irAE). However the laboratory tests revealed severe increment of liver enzymes and bilirubin (alanine aminotransferase - ALT, aspartat aminotransferase - AST, bilirubin, and gamma-glutamyl transferase GGT) shown in Graph 1 leading to immediate hospital admission. The patient had no past medical history of liver disease, elevated liver enzymes, druginduced liver injury, autoimmune disor-

\section{Event or finding}

Intervention

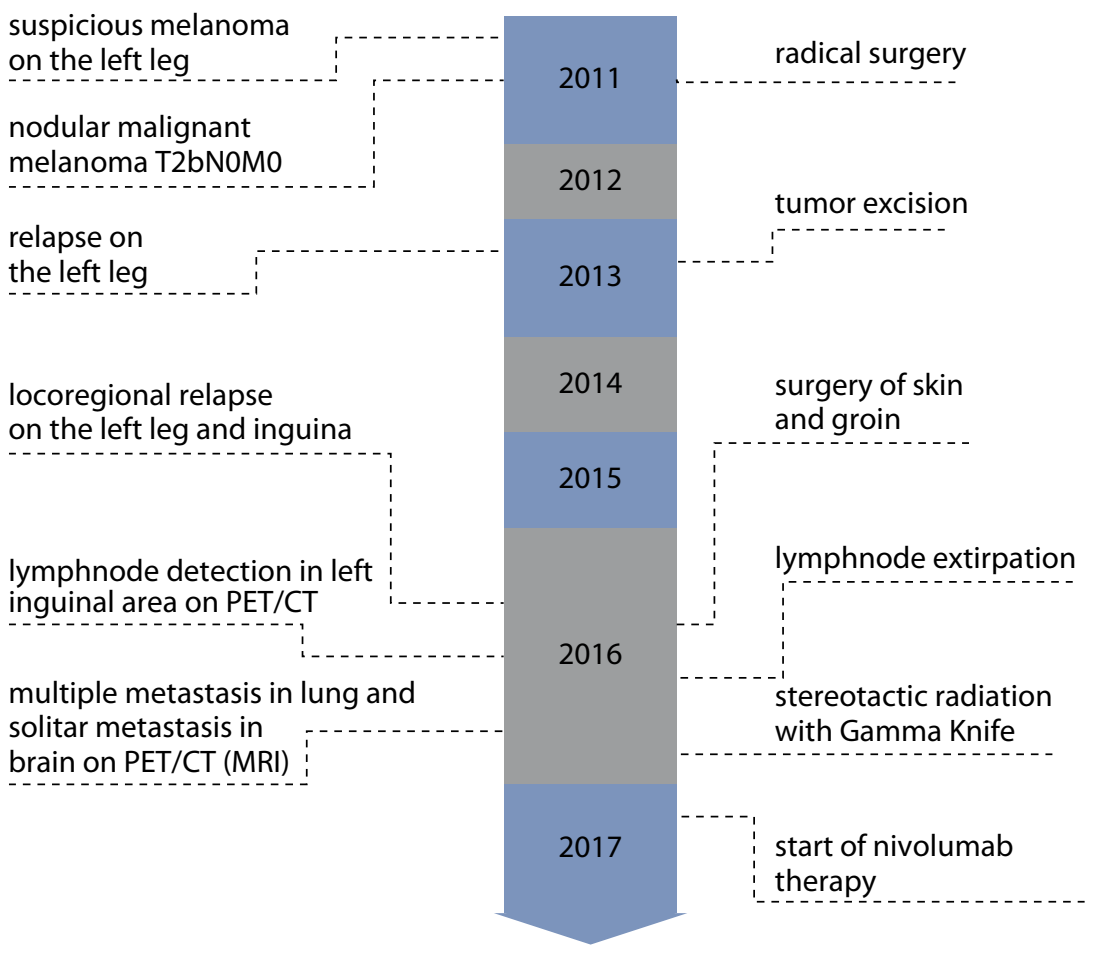

Schema 1. Disease history timeline. ders or any other significant comorbidities. There were no signs of metastatic involvement of the liver on previous computed tomography (CT) and current ultrasound imaging studies. Her medication did not include any drugs with known liver toxicity except for levetiracetam $1,500 \mathrm{mg} /$ day, administered as antiepileptic prophylaxis for brain metastases. Taking into account that rare cases of levetiracetam-induced hepatic failure were reported [4], the medication was switched to a less hepatotoxic drug, lamotrigine. However, considering that the liver functions did not resolve after cessation of levetiracetam, it was ruled out as a possible cause of liver toxicity and returned to the patient's medication.

In order to exclude all possible causes of liver injury, we performed a broad evaluation spectrum. At the beginning, drug or herbal intoxication was excluded, and the patient was tested for a panel of viral infections (human immunodeficiency virus - HIV, cytomegalovirus CMV, Epstein-Barr virus - EBV, herpes simplex virus type 1 - HSV-1, herpes simplex virus type 2 - HSV-2, hepatitis A virus HAV, hepatitis B virus - HBV, hepatitis $C$ virus - HCV, hepatitis E virus - HEV) with negative results. A screening for possible iron and copper metabolism disorders was also negative. The imaging methods showed no biliary tree distension, no signs of new liver metastases, nor brain metastases progression. Taking a step further, the patient was tested for possible autoimmune diseases, involving the assessment of autoantibodies (i.e. antineutrophil cytoplasmic antibodies ANCA, anti-mitochondrial antibodies AMA, anti-nuclear antibodies - ANA, antibodies to smooth muscle - SMA, anti-liver-kidney microsome antibodies anti-LKM, anti-soluble liver antigen antibodies - anti-SLA, antibody to liver cytosol - anti-LC-1, and rheumatoid factor), all of which were negative.

Considering that none of the previous tests provided any significant information regarding the aetiology of the hepatic lesion, the decision to perform a liver biopsy was made. The histopathological evaluation showed an oedema in the portal fields and mixed inflamma- 


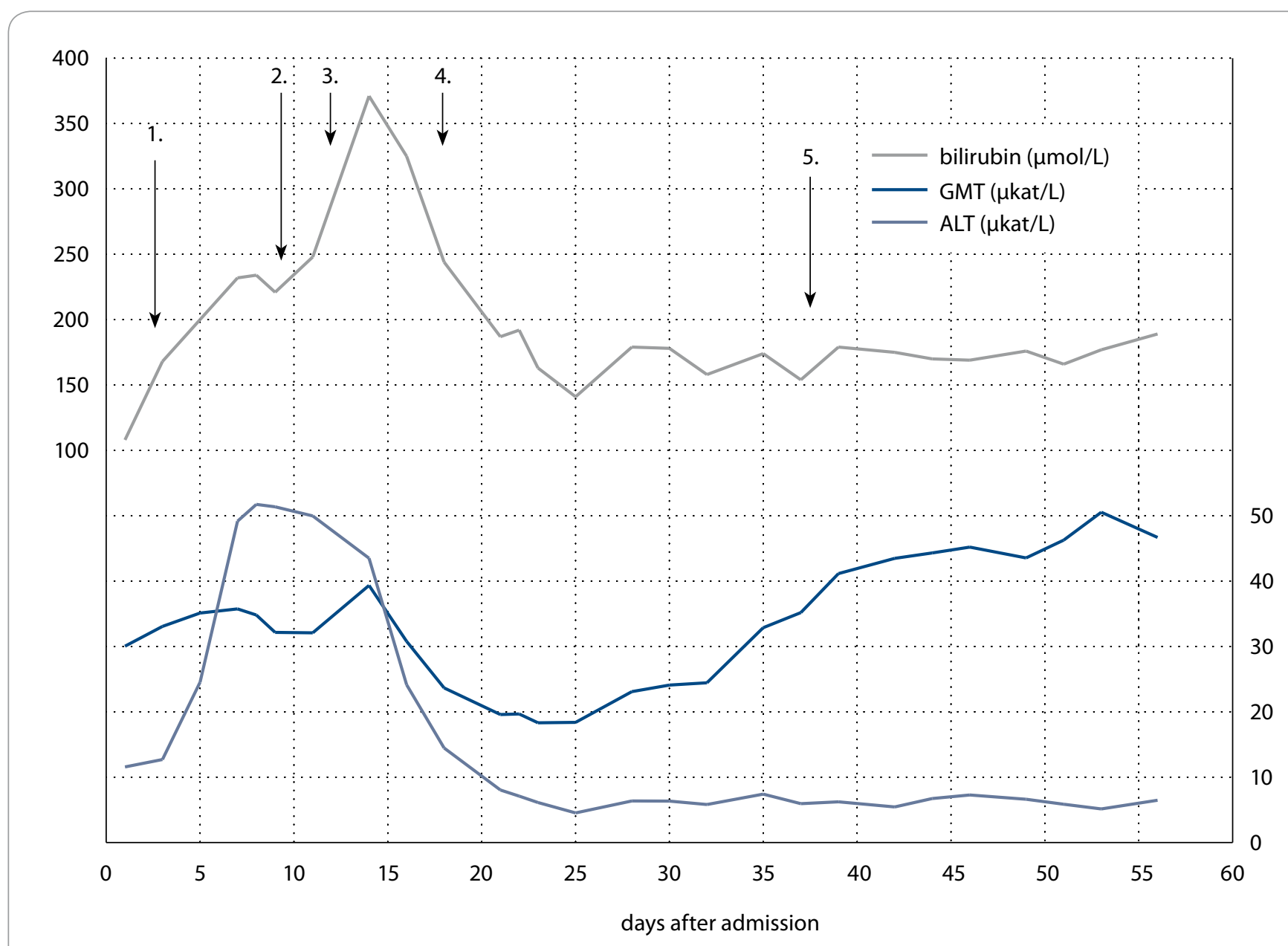

GMT - gamma-glutamyl transferase, ALT - alanine aminotransferase

Graph 1. Development of liver enzymes and therapeutical interventions.

Arrows indicate day and manner of intervention: 1) methylprednisolon $2 \mathrm{mg} / \mathrm{kg} / \mathrm{day} ; 2$ ) corticosteroids $4 \mathrm{mg} / \mathrm{kg} / \mathrm{day}+\mathrm{mycophenolate}$ mofetil $2 \mathrm{~g} /$ day; 3) methylprednisolon $6 \mathrm{mg} / \mathrm{kg} /$ day; 4) tapering of methylprednisolon to $2 \mathrm{mg} / \mathrm{kg} /$ day; 5 ) methylprednisolon $4 \mathrm{mg} / \mathrm{kg} / \mathrm{day}$.

tion consisting of eosinophilic and neutrophilic granulocytes. The major finding was a perivenular (zone 3) cholestasis. Fig. 1 shows the presence of bile both within the liver cell cytoplasm and the dilated canaliculi.

Following the recommendations for irAE management, the patient was started on methylprednisolone i.v. $2 \mathrm{mg} / \mathrm{kg} /$ day. Considering that the laboratory results and symptoms did not improve after a week of therapy, the dose of methylprednisolone was raised to $4 \mathrm{mg} / \mathrm{kg} /$ day and further to $6 \mathrm{mg} / \mathrm{kg} /$ day. Because of further deterioration of the clinical symptoms (jaundice, itching), the case was discussed within a multidisciplinary board, including gastroen- terologists and a neurologist, and the patient was started on mycophenolate mofetil 1g BID and acidum ursodeoxycholicum 1,500 mg/day (Graph 1).

While on combined immunosuppressive therapy, the patient developed multiple side effects, including blood count alteration (thrombocytopenia and neutropenia), thyroid function alteration (decreased thyroid-stimulating hormone), muscle weakness, loss of appetite, and mental discomfort. Considering this, together with partial restoration of liver function, we started to gradually taper the doses of corticosteroids and mycophenolate mofetil (Graph 1).

Despite the use of antibiotics and antimycotics prophylaxis (fluconazole, co-trimoxazole) during the immunosuppressive therapy, the patient developed a mild respiratory infection, which was promptly managed with antibiotics (cefotaxime).

Because of neurological symptoms (epileptic seizures, weakness of muscles with hemiplegic left upper extremity) recurring despite sufficient plasma levels of anti-epileptic drugs, progression of GGT and bilirubin serum levels, we performed brain magnetic resonance imaging and a chest, abdomen, and pelvis $C T$ scan. There were no new metastatic lesions in the brain. However, the CT scan revealed metastases progression in lungs, adrenal glands and liver. The limited therapeutic possibilities and 


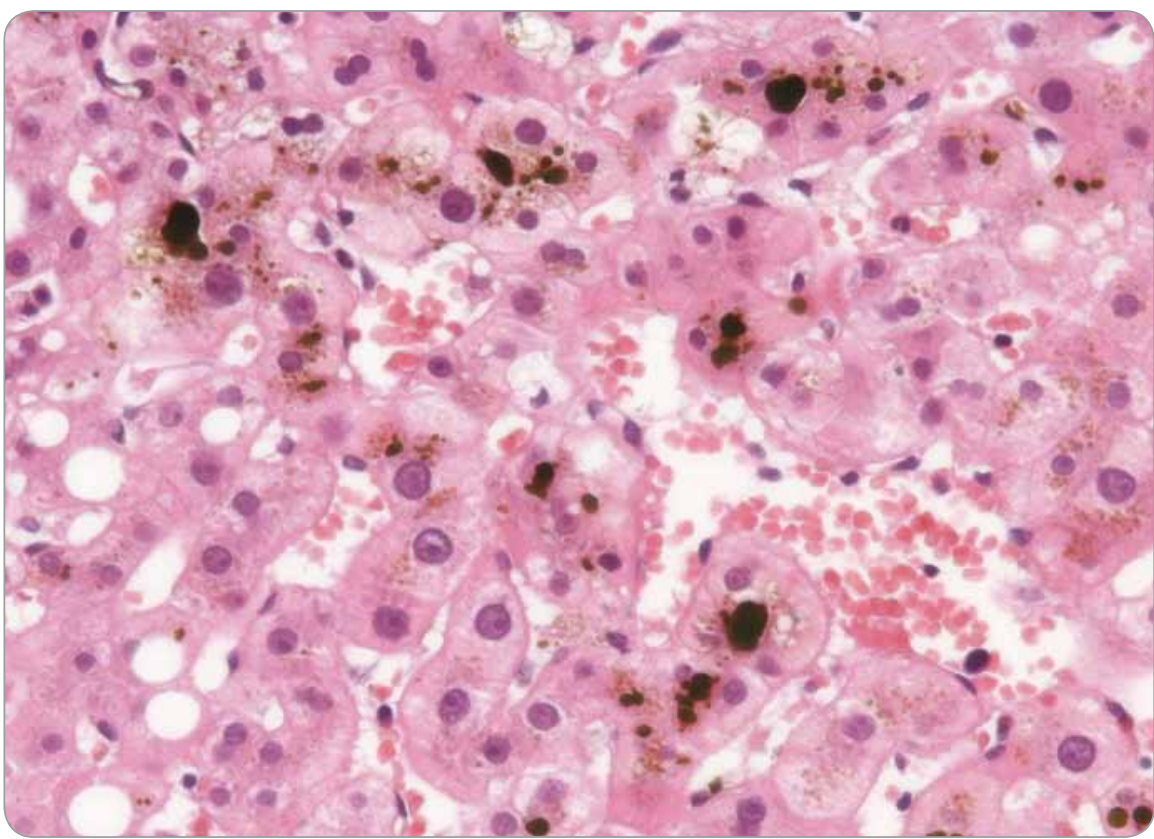

Fig. 1. Histological samples of liver tissue.

Hematoxylin and eosin staining showing the portal fields with mixed inflammation and predominantly intracelullar and canalicular cholestasis.

unfavourable prognosis was thoroughly discussed with the patient and her family. The consensus was made to provide the best supportive care. The patient eventually died 74 days following the first dose of nivolumab due to tumour progression.

\section{Discussion}

The introduction of immune checkpoint inhibitors has dramatically improved the prognosis of patients with metastatic melanoma; in this regard, nivolumab has significantly improved overall survival when compared to ipilimumab or to chemotherapy $[1,5]$.

Despite the important clinical benefits of nivolumab, immune checkpoint inhibition is associated with a broad spectrum of side effects, usually termed as irAEs, resulting from its mechanism of action, i.e. immune response enhancement [6].

Overall, the safety profile of nivolumab is favourable and any possible AEs are manageable and generally consistent. IrAEs include dermatologic, gastrointestinal, hepatic, endocrine, and other less common inflammatory events. There is no obvious pattern in the incidence, severity, or relation to nivolumab dos- age. Most irAEs are of low-grade (i.e. grade 1-2) with relatively few of highgrade (i.e. grade 3-4). Most high-grade events are managed with corticosteroids, tumour necrosis factor-alpha antagonists, or mycophenolate mofetil [7].

Although nivolumab-related liver toxicity has been reported in the past, it was usually present in low-grade form. In this regard, patients treated with nivolumab monotherapy within clinical trials (CA209066, CA209037, CA209067, CA209017, CA209057, CA209063, CA209025, CA209205, and CA209039), showed a $6.9 \%$ incidence of liver function abnormalities. An estimated $5.1 \%$ of patients presented usually mild effects (i.e. grade 1 or 2), whereas only $1.9 \%$ were classified as grade 3 or 4 . The onset of liver toxicity was usually observed after two to six cycles 1-3 months after treatment initiation (median 1.9 month). With appropriate medical therapy, most of these irAEs were resolved within a median of 5.4 weeks. Permanent discontinuation of the treatment was required in only $0.9 \%$ of patients [1,8-14].

Hepatic AEs induced by PD-1 inhibitors commonly shown as an asymptomatic increment of AST and ALT, and rarely of total bilirubin. Symptoms such as fatigue, fever, and hepatomegaly, detected by imaging methods, may also occur [15].

A correct diagnosis, along with the assessment of a hepatic lesion aetiology, requires the combination of laboratory tests and a liver biopsy; however, it may still be challenging to reveal the aetiology of the hepatic lesion. Clinical data may provide further information and aid in determining the diagnosis, i.e. the relation between therapy start and hepatotoxicity onset, resolution time after drug cessation, time of recurrence upon re-challenge, and previous evidence of drug hepatotoxicity [16]. The differential diagnosis includes drug-induced liver injury, idiopathic autoimmune hepatitis, acute viral hepatitis, and acute alcoholic liver disease. Distinguishing between idiopathic autoimmune hepatitis and drug-induced liver injury is much more challenging in case of immunotherapy, as these two forms of liver injury have similar clinical features [17].

Further information regarding any histopathological findings in patients with anti-PD-1 induced liver injury is rather scarce. Although there are some reports (usually individual case reports or small case series) of anti-CTLA-4 monoclonal antibodies induced liver toxicity $[18,19]$ with a similar pattern of liver injury caused by anti-PD-1 therapy. Histopathological findings of liver injury associated with anti-CTLA-4 therapy are usually described as acute hepatitislike pattern with focal or confluent necrosis and prominent portal inflammation. However, other pathological patterns have been reported and some proportion of cholestasis may also be present in some cases. The inflammatory infiltrate is composed predominantly of $\mathrm{CD}^{+}$T-lymphocytes, admixed histiocytes, scattered plasma cells, and eosinophils [18-20].

To the best of our knowledge, there are only two reported cases, including the histopathological findings of nivolumab-induced liver injury in a patient with lung cancer and glioblastoma [21,22], but none in melanoma. In the first case, the liver biopsy showed a moderate lymphocytic inflammatory infiltrate with bile duct injury and mild 
periportal necrosis. Immunohistochemical staining revealed the prevalence of $\mathrm{CD}^{+}{ }^{+} \mathrm{CD} 8^{+}$lymphocytes in the portal tract. In the latter case, the hepatocytes showed a diffuse cytoplasmic clearing, with occasional macro-vacuolar steatosis in the centrilobular area. The steatotic hepatocytes were surrounded by a rich inflammatory infiltrate, while in the portal tract, only a minimal fibrosis and scattered inflammatory cells were found. Again, the inflammatory infiltrate was represented mostly by $\mathrm{CD}^{+}$cytotoxic lymphocytes, diffusely scattered within the parenchyma.

In our case, the evaluation of the liver tissue by $C D 3 / C D 8$ immunohistochemical staining and PD-L1 expression analysis showed only a small number of $\mathrm{CD}^{+}$ cells in liver sinusoids and portal fields, whereas $\mathrm{CD}^{+}$cell presence was much richer at these sites. The $\mathrm{CD} 3: \mathrm{CD} 8$ ratio was $5: 1$ in favour of $\mathrm{CD}^{+}$cells. PD-L1 expression was mainly detected in the endothelial cells of liver sinusoids and, sporadically, in Kupffer cells; however, it was absent in hepatocytes.

Taking into account our findings with available case reports, it could be suggested that anti-PD-1 induced liver injury likely represents heterogeneous forms of disease, ranging from autoimmune hepatitis to other forms with predominant cholangitic liver disease. In contrast to both cases mentioned above, we present a new histopathological pattern involving intracellular and canalicular cholestasis with only a mild inflammatory infiltrate. In a similar manner to the case with cholangitic hepatitis [21], we also observed a worse response to corticosteroids; therefore suggesting that a predominant cholangiolitic pattern of liver injury might require different and much more intensive therapeutic strategies. However, the specific mechanisms involved in nivolumab-induced liver injury are currently unknown.

Hepatitis with cholestasis may be induced by a wide spectrum of drugs [17]. Cholestatic patterns of liver injury can be divided into three basic categories acute (bland or intrahepatic) cholestasis, chronic cholestasis, and a type of cholestasis termed as "cholestatic hepatitis". The histopathological findings in acute cholestasis usually involve bile plugs in canaliculi and bile accumulation in hepatocytes, particularly in zone 3, accompanied with mild inflammation. Chronic cholestasis pattern shows cholate stasis and periportal copper accumulation with some degree of induct injury. Histopathological findings of cholestatic hepatitis show a variable spectrum of inflammation and cholestasis, ranging from cases of acute hepatitis, involving a cholestatic component, to cases with minimal inflammation. The degree of inflammation in cholestatic hepatitis, predominantly consisting of neutrophilic infiltrates, tends to be less severe compared with a case of pure acute or chronic hepatitis [23].

In order to identify the correct cause of liver injury, cooperation within a multidisciplinary team, involving gastroenterologists, radiologists and preferably also pathologists, is important. The symptoms and findings might mimic other conditions, such as autoimmune hepatitis, primary biliary cholangitis, primary sclerosing cholangitis, viral hepatitis, or tumour progression, which need to be ruled out before being able to diagnose nivolumab induced immune-related liver injury.

Corticosteroids therapy is the mainstay of irAE management, in which the dose depends on a toxicity grade ranging from 0.5 to $2 \mathrm{mg} / \mathrm{kg} /$ day [24-26]. The response to corticosteroid therapy in immune mediated liver injury can be variable, especially in presence of a non-typical cholangitic pattern. When concerning our case (or a previously reported lung cancer case) [21], the response seems to be slower and the condition more resistant to immunosuppressive therapy; therefore, a higher initial dose of corticosteroids may be required. Alternatively, other immunosuppressive drugs, such as mycophenolate mofetil can be used. Regardless, it must be emphasised that patients treated with corticosteroids i.v. therapy are especially prone to infectious complications and adequate care should be paid to this issue.

\section{Conclusion}

Our case report shows the importance of vigilance from the first application of nivolumab and the necessity of regular follow-up. Special attention must be given to the fact that hepatotoxicity might represent a severe complication of immunotherapy with a potentially fatal outcome. In concordance with previously published data, we demonstrate that cholestatic hepatitis shows a poor response to corticosteroid therapy and may justify more potent upfront immunosuppressive treatment. In order to collect more data regarding histopathological patterns associated with anti-PD-1 therapy induced liver toxicity, liver biopsy in patients with severe hepatotoxicity is warranted.

\section{References}

1. Robert C, Long GV, Brady B et al. Nivolumab in previously untreated melanoma without BRAF mutation. N Engl J Med 2015; 372(4): 320-330. doi: 10.1056/NEJMoa1412082

2. Wang W, Lie P, Guo M et al. Risk of hepatotoxicity in cancer patients treated with immune checkpoint inhibitors: a systematic review and meta-analysis of published data. Int J Cancer 2017; 141(5): 1018-1028. doi: 10.1002/ijc.30678.

3. Zhang $X$, Ran $Y$, Wang $K$ et al. Incidence and risk of hepatic toxicities with PD-1 inhibitors in cancer patients: a meta-analysis. Drug Des Devel Ther 2016; 10: 3153-3161. doi: 10.2147/DDDT.S115493.

4. Tan TC, de Boer BW, Mitchell A et al. Levetiracetam as a possible cause of fulminant liver failure. Neurology 2008; 71(9): 685-686. doi: 10.1212/01.wnl.0000324604.11657.c6. 5. Larkin J, Chiarion-Sileni V, Gonzalez R et al. Combined nivolumab and ipilimumab or monotherapy in untreated melanoma. N Engl J Med 2015; 373(1): 23-34. doi: 10.1056/NEJMoa1504030

6. Naidoo J, Page DB, Li BT et al. Toxicities of the antiPD-1 and anti-PD-L1 immune checkpoint antibodies. Ann Oncol 2015; 26(12): 2375-2391. doi: 10.1093/annonc/mdv383.

7. Champiat S, Lambotte O, Barreau E et al. Management of immune checkpoint blockade dysimmune toxicities: a collaborative position paper. Ann Oncol 2016; 27(4): 559-574. doi: 10.1093/annonc/mdv623.

8. Weber JS, D'Angelo SP, Minor D et al. Nivolumab versus chemotherapy in patients with advanced melanoma who progressed after anti-CTLA-4 treatment (CheckMate 037): a randomised, controlled, open-label, phase 3 trial. Lancet Oncol 2015; 16(4): 375-384. doi: 10.1016/S14702045(15)70076-8.

9. Larkin J, Hodi FS, Wolchok JD. Combined nivolumab and ipilimumab or monotherapy in untreated melanoma. N Engl J Med 2015; 373(13): 1270-1271. doi: 10.1056/NEJMC1509660.

10. Borghaei H, Paz-Ares L, Horn L et al. Nivolumab versus docetaxel in advanced nonsquamous non-small-cell lung cancer. N Engl J Med 2015; 373(17): 1627-1639. doi: 10.1056/NEJMoa1507643

11. Rizvi NA, Mazieres J, Planchard D et al. Activity and safety of nivolumab, an anti-PD-1 immune checkpoint inhibitor, for patients with advanced, refractory squamous non-small-cell lung cancer (CheckMate 063): a phase 2 . single-arm trial. Lancet Oncol 2015; 16(3): 257-265. doi: 10.1016/S1470-2045(15)70054-9

12. Motzer RJ, Escudier B, McDermott DF et al. Nivolumab versus everolimus in advanced renal-cell carcinoma. 
N Engl J Med 2015; 373(19): 1803-1813. doi: 10.1056/NEJMoa1510665.

13. Younes A, Santoro A, Shipp M et al. Nivolumab for classical Hodgkin's lymphoma after failure of both autologous stem-cell transplantation and brentuximab vedotin: a multicentre, multicohort, single-arm phase 2 trial. Lancet Oncol 2016; 17(9): 1283-1294. doi: 10.1016/S1470-2045(16)30167-X

14. Ansell SM, Lesokhin AM, Borrello I et al. PD-1 blockade with nivolumab in relapsed or refractory Hodgkin's lymphoma. N Engl J Med 2015; 372(4): 311-319. doi: 10.1056/NEJMoa1411087.

15. Postow MA. Managing immune checkpoint-blocking antibody side effects. Am Soc Clin Oncol Educ Book 2015; 76-83. doi: 10.14694/EdBook_AM.2015. 35.76.

16. Aithal GP, Watkins PB, Andrade RJ et al. Case definition and phenotype standardization in drug-induced liver injury. Clin Pharmacol Ther 2011; 89(6): 806-815. doi: 10.1038/clpt.2011.58.
17. Kleiner DE. The histopathological evaluation of druginduced liver injury. Histopathology 2017; 70(1): 81-93. doi: $10.1111 /$ his.13082.

18. Johncilla M, Misdraji J, Pratt DS et al. Ipilimumab associated hepatitis: clinicopathologic characterization in a series of 11 cases. Am J Surg Pathol 2015 39(8): 1075-1084. doi: 10.1097/PAS.0000000000000 453.

19. Kleiner DE, Berman D. Pathologic changes in ipilimumab-related hepatitis in patients with metastatic melanoma. Dig Dis Sci 2012; 57(8): 2233-2240. doi: 10.1007/s10620-012-2140-5.

20. Hofmann L, Forschner A, Loquai C et al. Cutaneous, gastrointestinal, hepatic, endocrine, and renal side-effects of anti-PD-1 therapy. Eur J Cancer 2016; 60: 190-209. doi 10.1016/j.ejca.2016.02.025.

21. Gelsomino F, Vitale G, D'Errico A et al. Nivolumabinduced cholangitic liver disease: a novel form of serious liver injury. Ann Oncol 2017; 28(3): 671-672. doi: 10.1093/annonc/mdw649.
22. Simonelli M, Di Tommaso L, Baretti M et al. Pathological characterization of nivolumab-related liver injury in a patient with glioblastoma. Immunotherapy 2016; 8(12): 1363-1369. doi: 10.2217/imt-2016-0057.

23. Kleiner DE, Chalasani NP, Lee WM et al. Hepatic histological findings in suspected drug-induced liver injury: systematic evaluation and clinical associations. Hepatology 2014; 59(2): 661-670. doi: 10.1002/hep.26709.

24. Kumar V, Chaudhary N, Garg M et al. Current diagnosis and management of immune related adverse events (irAEs) induced by immune checkpoint inhibitor therapy. Front Pharmacol 2017; 8: 49. doi: 10.3389/fphar.2017.00049.

25. Lakomy R, Poprach A. Side effects of modern immunotherapy and how to solve them in the clinics. Klin Onkol 2015; 28 (Suppl 4): 4S103-4S114. doi: 10.14735/amko20154S103. 26. Kopecky J, Kubecek O, Trojanova P et al. Adverse effects of modern treatment of malignant melanoma and their treatment/management. Klin Onkol 2014; 27(6): 393-400. doi: 10.14735/amko2014393. 